This work is licensed under Creative Commons Attribution 4.0 International (CC BY 4.0). [http://creativecommons.org/licenses/by/4.0/]

\title{
Przysądzenie własności wydane w postępowaniu egzekucyjnym z nieruchomości wobec rozwiązań specustawy drogowej
}

Łukasz Kamiński | Uniwersytet Gdański https://orcid.org/0000-0003-4986-1840

Piotr Kamiński | Uniwersytet Gdański https://orcid.org/0000-0002-2622-3849

Słowa kluczowe:

droga publiczna, własność, wywłaszczenie, księga wieczysta, procedura

Keywords:

public road, property, expropriation, land registration, process

\section{Streszczenie}

Artykuł porusza kwestie procedury specustawy drogowej i jej specyficzne rozwiązania z punktu widzenia sądowego postępowania egzekucyjnego. Ograniczenie procedury wywłaszczeniowej i zmniejszenie formalizmu niewątpliwie przyczynia się do szybszego uzyskania prawa własności przez podmiot publicznoprawny. Jednakże z pozoru prosta procedura może spowodować powstanie znacznych komplikacji. Wydaje się bowiem, że procedura specustawy drogowej w żadnym zakresie nie przewiduje możliwości, by z nieruchomości nią objętej prowadzone było sądowe postępowanie egzekucyjne. Wydanie zaś w toku takiego postępowania postanowienia o przysądzeniu własności, które powoduje nabycie o charakterze pierwotnym, skutkuje pojawieniem się kolejnych problemów w zakresie ustalenia podmiotu właściciela. Powyższe z kolei może doprowadzić do tego, że pomimo przeprowadzonej procedury wywłaszczeniowej określonej w specustawie własność nieruchomości nie pozostanie przy podmiocie publicznoprawnym, a będzie przysługiwała nabywcy. Dodatkowo podmiot publicznoprawny, stosując jedynie procedurę specustawy, bez powiązania z innymi przepisami, będzie pozbawiony możliwości kwestionowania decyzji wydanych w sądowym postępowaniu egzekucyjnym.

\section{Adjudication of ownership issued in property enforcement proceedings against solutions of the road law (Summary)}

This article touches on question of road procedure and its specific solutions from the legal proceeding of execution's point of view. The restriction of dispossessions' procedure and decrease of formalism are undoubtedly the reason of having a proprietary right by legal person. Although it seems to be a simple procedure it can cause some complications. It appears that the road procedure does not predict any possibility to start a legal proceeding of execution when a property is included. During such proceedings when a decision about giving 
a property is passed, which causes an acquisition of original nature can be a reason of appearing another problems within the scope of deciding the legal person. Accordingly, it all can lead to such situation that despite proceeding a dispossessions' procedure, a property will not remain to the legal person, but will entitle to the purchaser. Additionally, the legal person will be lacked of possibility to question the decisions which are passed in legal proceeding of execution.

\section{Wstęp}

Ustawa z dnia 10 kwietnia 2003 r. o szczególnych zasadach przygotowania i realizacji inwestycji w zakresie dróg publicznych (Dz. U. Nr 80, poz. 721 z późn. zm.), zwana dalej ZasInwDrP, wprowadziła do systemu prawnego odbiegające od zwykłej procedury wywłaszczeniowej mechanizmy uzyskania prawa własności przez Skarb Państwa i jednostki samorządu terytorialnego. Sama nazwa ustawy sugeruje, że zawarte w niej rozwiązania są wyjątkami od reguły. Jako wyjątki nie powinny być zatem interpretowane rozszerzająco, zgodnie z zasadą exceptiones non sunt extendendae. Wprowadzone wyjątki nie powinny także powodować zamętu terminologicznego ani naruszać podstawowych zasad prawa, zaś przyjęte rozwiązania nie powinny odstawać od standardów tworzenia prawa, jak i jego obowiązywania (por. Wolian 2010: 24). Ustawa ta modyfikuje stosowanie przepisów rangi ustawowej, które miałyby zastosowanie w zwykłym postępowaniu wywłaszczeniowym. Modyfikacje te zostały określone wprost w samej ustawie (zob. art. 1, art. 11c, art. 11d ust. 3 i 4, art. 11f ust. 2, art. 11i, art. 11 j, art. 12 ust. 5, art. 16 ust. 3 , art. 17 ust. 5, art. 21, art. 22 ust. 1, art. 23, art. 31, art. 32 ust. 1, art. 42 ust. 1, art. 43 ust. 2 oraz art. 44 ZasInwDrP), co jednak nie uzasadnia twierdzenia o zupełnej odrębności unormowanego w niej postępowania od innych regulacji.

Ustawa nie wyłącza ani nie modyfikuje pozostałych uregulowań rangi ustawowej (por. Wolian 2010: 28), tj. innych niż wskazane wyżej. Powyższe znajduje potwierdzenie w treści art. 1 ust. 1 ZasInwDrP, który wyznacza zakres jej unormowania. Zgodnie z jego treścią ustawa określa zasady i warunki przygotowania inwestycji w zakresie dróg publicznych, a także organy właściwe w tych sprawach (art. 1 ust. 2 i 3 ZasInwDrP). Ustawa nie określa omawianych w niniejszym opracowaniu szeroko rozumianych kwestii cywilnych, związanych między innymi z ujawnieniem prawa własności w treści księgi wieczystej nieruchomości.

Prawo własność pełni szczególną rolę w obrocie gospodarczym oraz stanowi podstawę funkcjonowania demokratycznego państwa prawa. Powyższe znajduje potwierdzenie rangi konstytucyjnej (zob. art. 20, art. 21 i art. 64 Konstytucji). Najistotniejszy dla rozważanej problematyki jest art. 21 ust. 1 ustawy zasadniczej, który określa przesłanki warunkujące wywłaszczenie, wskazując, że jest ono dopuszczalne jedynie wówczas, gdy jest dokonywane na cele publiczne i za słusznym odszkodowaniem. Powyższe per se wskazuje na brak cechy nienaruszalności i stałości prawa własności, w określonych 
sytuacjach zmiana właściciela jest niezbędna (Skrzydło 2013: 34). W celu dokonania wywłaszczenia lege artis niezbędne jest spełnienie dwóch warunków, tj. wywłaszczenia na cele publiczne oraz wywłaszczenia dokonanego za słusznym odszkodowaniem.

Wydaje się, co stanowi wstępne założenie opracowania, że nabycie własności w drodze postanowienia o przysądzeniu własności wydanego w sądowym postępowaniu egzekucyjnym, która to procedura zostanie omówiona poniżej, będzie korzystało ze szczególnej ochrony wynikającej z istoty samego postanowienia, które jest wydawane przez sąd i korzystać powinno ze szczególnego zaufania. Rozwiązania ZasInwDrP mogą jednak powodować sprzeczność pomiędzy normami regulującymi uprawnienia nabywcy-licytanta a podmiotu publicznoprawnego, wynikających z ZasInwDrP.

\section{Procedura ZasInwDrP}

Kluczowym elementem omawianej ustawy jest decyzja o zezwoleniu na realizację inwestycji drogowej. Jest ona wydawana przez wojewodę w odniesieniu do dróg krajowych i wojewódzkich albo przez starostę w odniesieniu do dróg powiatowych i gminnych (art. 11a ZasInwDrP). Decyzja musi być wydana w ciągu 90 dni od chwili zgłoszenia wniosku odpowiedniego podmiotu, tj. zarządcy drogi (art. 11a ust. 3 ZasInwDrP). Tak krótki termin nie może jednak powodować całkowitego pominięcia analizowanych w niniejszej pracy aspektów prawa własności. Organ nie może ograniczać się bowiem do prostej, jedynie formalnej weryfikacji wniosku. Przy wydawaniu decyzji powinny zostać zbadane elementy, takie jak bezwzględna konieczność pozbawienia prawa własności i stopień ingerencji w to prawo (wyrok WSA w Łodzi z dnia 4 lipca 2013 r., II SA/Łd 535/13).

Właściwy wniosek może być złożony po uzyskaniu przez zarządcę opinii właściwych miejscowo zarządu województwa, zarządu powiatu oraz wójta, względnie burmistrza albo prezydenta miasta (art. 11 b ust. 1 ZasInwDrP). Niewydanie opinii w terminie 14 dni od dnia zwrócenia się przez właściwego zarządcy drogi o jej wyrażenie traktuje się jako brak zastrzeżeń do wniosku (art. 11b ust. 2 ZasInwDrP). Do nieruchomości stanowiących rodzinne ogrody działkowe, objętych decyzją o zezwoleniu na realizację inwestycji drogowej, nie stosuje się przepisów regulujących ich likwidację (określonych w treści art. 18-24 ustawy z dnia 13 grudnia 2013 r. o rodzinnych ogrodach działkowych, Dz. U. z 2014 r. poz. 40 z późn. zm.).

Celem ZaslnwDrP jest przyśpieszenie procesu związanego z wydaniem decyzji oraz ograniczenie uprawnień podmiotów, $z$ wyjątkiem inwestora, do praw strony w postępowaniu administracyjnym. Tak istotne ograniczenie stosowania ustawy z dnia 14 czerwca 1960 r. - Kodeks postępowania administracyjnego (Dz. U. Nr 30, poz. 168 z późn. zm.) (dalej: k.p.a.) wymaga uzasadnienia nie tylko na gruncie aksjologicznym, ale także $z$ uwagi na szeroko pojęte dobro publiczne. Tym niemniej nie znajduje się podstaw do wyłączenia wszystkich zasad postępowania administracyjnego. Wobec powyższego, stosownie do treści art. 7 k.p.a. i wyrażonej w jego treści zasady prawdy 
obiektywnej, organ powinien podjąć wszelkie kroki do dokładnego wyjaśnienia stanu faktycznego sprawy (wyrok WSA w Łodzi z dnia 4.07.2013, II SA/Łd 535/13). Organ jest zobowiązany do wszechstronnej oceny zgromadzonego materiału dowodowego i uzasadnienia decyzji, zgodnie z ogólnymi wymaganiami k.p.a.

Planowanie drogi nie może być zabiegiem czysto formalnym, ograniczającym się jedynie do przedłożenia odpowiedniego projektu, bez badania interesu prywatnego właścicieli nieruchomości. W demokratycznym państwie prawa nie istnieje automatyzm pierwszeństwa interesu publicznego nad interesem prywatnym. Powyższe oznacza, że każdy przypadek należy traktować indywidualnie, a organ ma obowiązek określić interes publiczny i wykazać, że jest on na tyle ważny i znaczący, że wymaga ograniczeń uprawnień indywidualnych obywateli i nie da się go zrealizować przy użyciu innych metod (wyrok SN z dnia 18.11.1993, III ARN 49/93). Istnienie interesu publicznego oraz przesłanek uzasadniających pozbawienie prawa własności musi podlegać kontroli instancyjnej i sądowej.

W zakresie obowiązku poinformowania określonych podmiotów art. 11d ust. 5 ZasInwDrP wskazuje, że wojewoda w odniesieniu do dróg krajowych i wojewódzkich albo starosta w odniesieniu do dróg powiatowych i gminnych wysyłają zawiadomienie o wszczęciu postępowania w sprawie wydania decyzji o zezwoleniu na realizację inwestycji drogowej wnioskodawcy, właścicielom lub użytkownikom wieczystym nieruchomości objętych wnioskiem o wydanie tej decyzji na adres wskazany w katastrze nieruchomości. W przypadku, o którym mowa w art. 11 a ust. 2 ZasInwDrP, zawiadomienie wysyłane jest także wojewodom, na których obszarze właściwości znajduje się część nieruchomości objętej wnioskiem o wydanie decyzji o zezwoleniu na realizację inwestycji drogowej. Pozostałe strony zawiadamiane są w drodze obwieszczeń, odpowiednio w urzędzie wojewódzkim lub starostwie powiatowym, a także w urzędach gmin właściwych ze względu na przebieg drogi, w urzędowych publikatorach teleinformatycznych - Biuletynie Informacji Publicznej tych urzędów i w prasie lokalnej (art. 11d ust. 5 zd. 1 ZasInwDrP). Zawiadomienie musi zawierać w szczególności oznaczenie nieruchomości lub ich części według katastru nieruchomości oraz informację o terminie i miejscu, w którym strony mogą zapoznać się z aktami sprawy (art. 11d ust. 6 ZasInwDrP).

Podkreślić przy tym należy, że doręczenie zawiadomienia na adres wskazany w katastrze nieruchomości jest skuteczne (art. 11d ust. 5 zd. 2 ZasInwDrP). Jest to istotne ułatwienie w zakresie prowadzonego postępowania. Organ musi bowiem udokumentować nie fakt skutecznego doręczenia zawiadomienia stronie (właścicielowi), ale jedynie potwierdzenie jej nadania, z uwzględnieniem doręczenia zastępczego, na adres właściciela widniejący w katastrze nieruchomości (ewidencji gruntów i budynków, zgodnie z art. 53a ustawy z dnia 17 maja 1989 r. - Prawo geodezyjne i kartograficzne, Dz. U. Nr 30, poz. 163 z późn. zm.) (dalej: Pr. Geod.). 
Powyższe może prowadzić do braku faktycznego poinformowania właściciela o toczącej się procedurze. Co prawda zgodnie z treścią art. 22 ust. 2 Pr. Geod. właściciele nieruchomości mają obowiązek zgłoszenia właściwemu staroście zmiany danych objętych ewidencją gruntów i budynków, w terminie 30 dni, licząc od dnia powstania tych zmian, jednakże obowiązek ten jest częstokroć niedopełniany. Niezależnie od powyższego wskazać należy, że zgodnie ze zdaniem drugim wskazanego artykułu obowiązek ten nie dotyczy zmian danych objętych ewidencją gruntów i budynków, wynikających z aktów normatywnych, prawomocnych orzeczeń sądowych, decyzji administracyjnych, aktów notarialnych, materiałów zasobu, wpisów w innych rejestrach publicznych oraz dokumentacji architektoniczno-budowlanej przechowywanej przez organy administracji architektoniczno-budowlanej.

Kluczową kwestią jest zatem sposób ustalenia właściciela przez organ prowadzący postępowanie. Odesłania zawarte w omawianej ustawie nie wskazują, na jakiej podstawie ma zostać ustalony ten podmiot, w szczególności nie odsyłają do treści księgi wieczystej nieruchomości. Wobec wskazanego wyżej obowiązku doręczenia zawiadomienia na adres wskazany w katastrze nieruchomości przyjąć należy, że właściciel będzie ustalony właśnie w oparciu o te dane. Organ zobowiązany do dokonania doręczenia w oparciu o zapisy katastru nieruchomości nie będzie poszukiwał tego podmiotu w innych rejestrach.

Rozwiązanie to ocenić należy jako niewłaściwe. Po pierwsze, jest ono odmienne od podstawowego postępowania wywłaszczeniowego (unormowanego w ustawie z dnia 21 sierpnia 1997 r. o gospodarce nieruchomościami, Dz. U. Nr 115, poz. 741 z późn. zm.; dalej: ust. o gosp. nieruch.). Wskazana ustawa określa nieruchomość o nieuregulowanym stanie prawnym, przez którą rozumie się nieruchomość, dla której ze względu na brak księgi wieczystej, zbioru dokumentów albo innych dokumentów nie można ustalić osób, którym przysługują do niej prawa rzeczowe, oraz nieruchomość, której właściciel lub użytkownik wieczysty nieruchomości nie żyje i nie przeprowadzono lub nie zostało zakończone postępowanie spadkowe (art. 113 ust. 6 i 7 ust. o gosp. nieruch.). Jeżeli nieruchomość nie ma założonej księgi wieczystej lub zbioru dokumentów, przy jej wywłaszczeniu przyjmuje się inne dokumenty stwierdzające prawa do nieruchomości oraz służące do jej oznaczenia dane z katastru nieruchomości (art. 113 ust. 4 ust. o gosp. nieruch.).

Dane zawarte w księdze wieczystej są $w$ tym postępowaniu podstawą do prowadzenia dalszych czynności (zob. art. 116 ust. 1 pkt 1 i ust. 2 pkt 4, art. 119 ust. 1 pkt 2, art. 123 ust. 1 ust. o gosp. nieruch.). Ponadto następuje ujawnienie procedury wywłaszczeniowej w samej treści księgi wieczystej, celem uchylenia rękojmi wiary publicznej ksiąg wieczystych. Zgodnie z treścią art. 117 ust. 1 ust. o gosp. nieruch. starosta, wykonujący zadanie z zakresu administracji rządowej, składa w sądzie wniosek o ujawnienie w księdze wieczystej wszczęcia postępowania wywłaszczeniowego, a jeżeli nieruchomość nie ma założonej księgi wieczystej, o złożenie do istniejącego zbioru dokumentów zawiadomienia o wszczęciu tego postępowania. 
Po drugie, ewidencja gruntów i budynków nie korzysta z żadnych szczególnych unormowań. Konstrukcja księgi wieczystej zakłada szczególną rolę i domniemania wskazane niżej. Dane zgromadzone w ewidencji gruntów i budynków, niewątpliwie użyteczne z punktu widzenia działania administracji, nie korzystają z domniemania prawdziwości i takich atutów, jak dane zgromadzone w treści ksiąg wieczystych To właśnie księgi wieczyste zapewniają bezpieczeństwo i pewność obrotu nieruchomościami (zob. Gniewek 2013: 140).

Swoje funkcje księgi wieczyste mogą spełniać dzięki zasadzie jawności (art. 2 zd. 1 ustawy z dnia 6 lipca 1982 r. o księgach wieczystych i hipotece, Dz. U. Nr 19, poz. 147 z późn. zm.; dalej: u.k.w.h.) oraz domniemaniom, w szczególności domniemaniu wpisaniu prawa zgodnie z rzeczywistym stanem prawnym (art. 3 ust. 1 i 2 u.k.w.h.) i rękojmi wiary publicznej ksiąg wieczystych (art. 5 u.k.w.h.). Wskazany rejestr nieruchomości odgrywa inną rolę. Dane zawarte w tym rejestrze służą za podstawę planowania gospodarczego i przestrzennego, określeniu wymiaru podatku oraz celom statystycznym. Funkcją katastru nieruchomości jest zatem ułatwieniem organom państwa i jednostkom samorządu terytorialnego wykonywanie zadań związanych z nieruchomościami, co przesądza o informacyjnym charakterze rejestru (Gniewek 2013: 141).

Organ prowadzący postępowanie nie ma obowiązku informowania o wszczęciu postępowania podmiotów, które mogą być zainteresowane w zapadłym rozstrzygnięciu. Chodzi w tym miejscu w szczególności o wierzyciela hipotecznego, choć jego prawo do uzyskania odszkodowania zostało wprost wskazane w art. 18 ust. 1c ZasInwDrP, oraz o komornika, który może prowadzić postępowanie egzekucyjne z nieruchomości objętej postępowaniem.

Zawiadomienie tych podmiotów w drodze wskazanych obwieszczeń i ogłoszeń w prasie lokalnej może nie spełniać funkcji informacyjnych. Wątpliwe jest bowiem, aby komornik prowadzący postępowanie egzekucyjne weryfikował przy każdej czynności obwieszczenia i ogłoszenia, w szczególności gdy stan prawny nieruchomości jest znany na podstawie treści księgi wieczystej. Trudno przypuszczać także, aby wierzyciel hipoteczny lub egzekwujący, który może mieć miejsce zamieszkania lub siedzibę poza granicami dokonanych obwieszczeń, interesował się ewentualnymi decyzjami wydawanymi przez podmiot prowadzący postępowanie na podstawie ZasInwDrP. Nałożenie takiego obowiązku, tj. konieczności weryfikacji obwieszczeń i ogłoszeń, czy raczej wiązanie z brakiem takiego zachowania negatywnych dla tych podmiotów następstw, byłoby niezgodne z konstytucyjnie chronionymi prawami.

Dla nieruchomości o nieuregulowanym stanie prawnym wojewoda w odniesieniu do dróg krajowych i wojewódzkich albo starosta w odniesieniu do dróg powiatowych i gminnych wysyłają wskazane wyżej zawiadomienie jedynie wnioskodawcy (art. 11d ust. 7 ZasinwDrP). Pod pojęciem nieruchomości o nieuregulowanym stanie prawnym należy, na gruncie ZasInwDrP, rozumieć sytuację, w której ze względu na brak danych co do osoby właściciela nie można dokonać zawiadomienia, nie zaś sytuację, 
w której dana nieruchomość nie ma w ogóle właściciela. Brak podmiotu właściciela można przypisać jedynie ruchomościom (zob. art. 180 i 181 ustawy z dnia 23 kwietnia 1964 r. - Kodeks cywilny, Dz. U. Nr 16, poz. 93 z późn. zm. [dalej: k.c.]; zob. też art. 113 ust. 6 ust. o gosp. nieruch.). Zawiadomienie jest wysyłane także jedynie wnioskodawcy, gdy właściciel lub użytkownik wieczysty nie żyją, a ich spadkobiercy nie wykazali prawa do spadku (art. $11 \mathrm{f}$ ust. 5 ZasInwDrP). Takie rozwiązanie powoduje wskazane wyżej komplikacje, tj. brak świadomości zainteresowanych podmiotów o toczącym się postępowaniu. Wąskie ujęcie stron postępowania budzi wątpliwości co do prawidłowości i zgodności z unormowaniem k.p.a.

Nadto doręczenie zawiadomienia w zakresie nieruchomości stanowiących własność Skarbu Państwa lub jednostek samorządu terytorialnego powoduje, że nie mogą być one przedmiotem obrotu w rozumieniu przepisów ust. o gosp. nieruch. (art. 11d ust. 9 ZasInwDrP). Czynność prawna dokonana z naruszeniem powyższego zakazu jest nieważna, co jest dodatkowym skutkiem doręczenia zawiadomienia wobec wskazanych podmiotów (art. 11d ust. 10 ZasInwDrP).

Po przeprowadzeniu postępowania nieruchomości lub ich części stają się z mocy prawa własnością Skarbu Państwa w odniesieniu do dróg krajowych albo własnością odpowiednich jednostek samorządu terytorialnego w odniesieniu do dróg wojewódzkich, powiatowych i gminnych (art. 12 ust. 4 ZasInwDrP). Przejście prawa własności następuje z dniem, w którym decyzja o zezwoleniu na realizację inwestycji drogowej stała się ostateczna (art. 12 ust. 4 in fine ZasInwDrP). Użytkowanie wieczyste ze wskazanym dniem wygasa, niezależnie od podstawy jego nabycia. Nabycie prawa własności następuje ipso iure. Nie stanowi elementu decyzji, a jedynie jej skutek, który wystąpi niezależnie od woli organu prowadzącego postępowanie albo wnioskodawcy, a zależy jedynie od prawnej oceny dopuszczalności wyznaczenia pasa drogowego w określonym miejscu (Wolian 2010: 230).

Wypłacenie odszkodowania nie uzależnia w jakikolwiek sposób przejścia prawa własności. Jest konsekwencją konstytucyjnego unormowania ograniczenia prawa własności, jednak uregulowania zawarte w ZasInwDrP nie są w tym zakresie jednoznaczne. Ponadto gdy na nieruchomości lub prawie użytkowania wieczystego zostały ustanowione ograniczone prawa rzeczowe z dniem, w którym decyzja o zezwoleniu na realizację inwestycji drogowej stała się ostateczna, prawa te wygasają (art. 12 ust. 4c ZasInwDrP). Powoduje to bezskuteczność umów zawartych przez podmiot wywłaszczany wobec podmiotu publicznoprawnego (zob. Bagińska, Parchomiuk 2010: 439).

\section{Ujawnienie prawa własności}

Organ wydający decyzję o zezwoleniu na realizację inwestycji drogowej posiada kompetencje do dokonania stosownych zmian we właściwych rejestrach, tj. w katastrze nieruchomości i księdze wieczystej - wydana decyzja stanowi podstawę do dokonania wpisów w tychże rejestrach (art. 12 ust. 3 ZasInwDrP). Jak jednak zostało wskazane 
wyżej, ewidencja gruntów i budynków nie stanowi rejestru, który korzystałby ze szczególnych walorów.

Rejestrem takim są księgi wieczyste i to właśnie w nich organ powinien ujawnić prawo własności. Zmiany nie są jednak dokonywane z urzędu. Powinnością organu jest zgłoszenie zmian do sądu wieczystoksięgowego (Wolian 2010: 222). Obowiązek ten wynika z treści art. 36 ust. 1 u.k.w.h., przewidującej konieczność przekazania informacji o zmianie właściciela (Wolian 2010: 223). Podstawy do ujawnienia prawa własności można upatrywać także $w$ art. 35 ust. 1 u.k.w.h., zgodnie z treścią którego właściciel nieruchomości jest obowiązany do niezwłocznego złożenia wniosku o ujawnienie swego prawa w księdze wieczystej. Obowiązek ten powstaje niezależnie od podstawy nabycia prawa własności, a więc także w przypadku nabycia ipso iure (Kućka 2014: 535). Powyższe jest aktualne z tym zastrzeżeniem, że nabycie własności nie nastąpiło w wyniku czynności prawnej, dla ważności której jest zastrzeżona forma aktu notarialnego (Rudnicki 2010: 223). W takim bowiem wypadku obowiązek odpowiedniego zgłoszenia będzie ciążył na notariuszu (art. 92 §4 ustawy z dnia 14 lutego 1991 r. Prawo o notariacie, Dz. U. Nr 22, poz. 91 z późn. zm.).

Pomimo obowiązku ujawnienia zmiany prawa własności w treści księgi wieczystej, ewentualny brak tego ujawnienia nie spowoduje dla organu (wnioskodawcy) większych komplikacji. Skoro została wydana decyzja, to wpisany w księdze wieczystej właściciel nie może przenieść w drodze czynności prawnej na inną osobę własności nieruchomości, zgodnie z zasadą nemo plus iuris. Kwestią sporną byłoby jedynie ustalenie podmiotu uprawnionego do odszkodowania, w razie zmiany podmiotu właściciela, natomiast własność nieruchomości pozostaje dalej przy podmiocie publicznym, a inwestycja może być realizowana. Takie rozumowanie może prowadzić jednak do negatywnych następstw dla tego podmiotu, łącznie z utratą prawa własności, ale w ramach innych zdarzeń prawnych niż czynności prawne.

\section{Postępowanie egzekucyjne}

Naturalnie może się zdarzyć, że nieruchomość objęta postępowaniem wskazanym wyżej jest zajęta w toku postępowania egzekucyjnego. Organ egzekucyjny dokonuje zajęcia nieruchomości poprzez wpis ostrzeżenia w jej księdze wieczystej (art. 925 § 1 zd. 2 ustawy z dnia 17 listopada 1964 r. - Kodeks postępowania cywilnego, Dz. U. Nr 43, poz. 296 z późn. zm.; dalej: k.p.c.). Zajęcie nieruchomości i trwające postępowanie egzekucyjne nie wpływa jednak na niemożliwość wydania wskazanej decyzji. Wydaje się, że przyznane odszkodowanie będzie stanowiło przynajmniej odpowiednik kwoty uzyskanej z egzekucji nieruchomości i będzie rozdzielone zgodnie z zasadami jej podziału (art. 1025 k.p.c.), nie zaś zgodnie z zasadami wypływającymi z ZasInwDrP.

Postępowanie prowadzone przez organ egzekucyjny może zakończyć się wydaniem przez sąd postanowienia o przysądzeniu własności na rzecz osoby, która wypełniła warunki licytacyjne (art. 998 § 1 k.p.c.). Postanowienie to może wywołać dalsze 
komplikacje związane z ustaleniem podmiotu właściciela, bowiem z chwilą uprawomocnienia się postanowienia o przysądzeniu własności wygasają wszelkie prawa i skutki ujawnienia praw i roszczeń osobistych ciążących na nieruchomości (art. 1000 $\S 1$ zd. 1 k.p.c.). Na miejsce tych praw powstaje prawo do zaspokojenia z ceny nabycia z pierwszeństwem przewidzianym w przepisach o podziale ceny uzyskanej z egzekucji (art. 1000 § 1 zd. 2 k.p.c.).

Zauważyć należy, że nie wszystkie prawa wygasają, bowiem pozostają w mocy bez potrącenia ich wartości z ceny nabycia prawa ciążące na nieruchomości z mocy ustawy, służebność drogi koniecznej, służebność ustanowiona w związku z przekroczeniem granicy przy wznoszeniu budowli lub innego urządzenia oraz służebność przesyłu (art. 1000 § 2 k.p.c.). Pozostają również w mocy ujawnione przez wpis w księdze wieczystej lub złożenie dokumentu do zbioru albo nieujawnione $w$ ten sposób, lecz zgłoszone najpóźniej na trzy dni przed terminem licytacji, użytkowanie, służebności i prawa dożywotnika, jeżeli przysługuje im pierwszeństwo przed wszystkimi hipotekami lub jeżeli nieruchomość nie jest hipotekami obciążona albo jeżeli wartość użytkowania, służebności i praw dożywotnika znajduje pełne pokrycie w cenie nabycia (art. $1000 \S 3$ zd. 1 k.p.c.). Jednakże w wypadku ostatnim wartość tych praw będzie zaliczona na cenę nabycia (art. 1000 § zd. 2 k.p.c.).

Zasadą jest jednak wygaśnięcie wszelkich praw z chwilą uprawomocnienia się postanowienia o przysądzeniu własności i prawo do uzyskania zaspokojenia z ceny nabycia. (zob. Langa-Bieszki, Świeczkowski 2005: 417). Prawomocne postanowienie o przysądzeniu własności posiada szczególny charakter. Podjęcie decyzji o uczestnictwie w licytacji publicznej podyktowane jest zaufaniem do organów państwa, w szczególności sądu. Wskazuje się, że nabywca nie powinien liczyć się z prawami innych osób, które nie zostały przewidziane $w$ treści art. 1000 \& 2, 3 i 4 oraz art. 1001 k.p.c. (postanowienie SN z dnia 18.09.2014, V CSK 533/13). Ponadto postanowienie o przysądzeniu własności ma charakter kształtujący, skutkuje nabyciem własności przez nabywcę oraz utratę prawa przez właściciela.

Przyjmuje się, że nabycie $w$ drodze licytacji jest nabyciem pierwotnym, a zatem nabycie prawa własności jest niezależne od tego, jaki podmiot był poprzednim właścicielem (postanowienie SN z dnia 13.06.2013, IV CSK 666/12). Postanowienie to skutkuje także tym, że treść księgi wieczystej w chwili jego wydania nie może być podstawą do innych ustaleń od poczynionych w tym orzeczeniu. Następuje wyłączenie rękojmi wiary publicznej ksiąg wieczystych (wynikającej z art. 6-9 u.k.w.h.). Nie występuje konieczność weryfikacji dopełnienia przez nabywcę aktów staranności, zapoznania się z treścią księgi wieczystej ani działania w dobrej bądź złej wierze (wyrok SN z dnia 22.09.1997, II CKN 730/97). 


\section{Zakres czasowy}

Kolejnym elementem w badanym aspekcie jest zakres czasowy trwania prawa własności przy podmiocie publicznym, na rzecz którego nastąpiło jego przeniesienie w wyniku wydanej decyzji na podstawie ZasInwDrP. Datą początkową - jak wskazano wyżej - jest dzień, w którym decyzja o zezwoleniu na realizację inwestycji drogowej stała się ostateczna.

Wskazać należy, że żaden przepis nie stanowi, że uzyskana w drodze procedury ZasInwDrP własność miałaby pozostać przy tym podmiocie na zawsze. Takie założenie byłoby zresztą sprzeczne z samą instytucją własności, która jest prawem zbywalnym.

Prowadzi to do wniosku, że uzyskana na podstawie przedstawionej wyżej procedury własność może wskutek zaistniałych zdarzeń prawnych zostać przeniesiona na inny podmiot. Pogląd podobny został wyrażony na gruncie wywłaszczenia na podstawie ust. o gosp. nieruch. Inne niż Skarb Państwa i jednostki samorządu terytorialnego podmioty mogą uzyskać prawo własności wywłaszczonej nieruchomości, ale na podstawie czynności prawnych, które zostaną dokonane po wywłaszczeniu (Mzyk 2012: 672). Oznacza to, że po wydaniu decyzji wydanej na podstawie ZasInwDrP i uzyskaniu prawa własności przez podmiot publicznoprawny, na skutek pewnych zdarzeń prawnych, jak wskazane postanowienie o przysądzeniu własności, podmiot publicznoprawny może utracić uprzednio uzyskaną własność.

\section{Utrata własności na podstawie orzeczenia sądu}

Dla przejścia prawa własności w ramach postępowania egzekucyjnego nie stanowią przeszkody prawa osób trzecich, pod warunkiem że nie zostały zgłoszone i wykazane (art. 953 § 1 pkt 6 k.p.c.). Powoduje to, że dla skutków postępowania egzekucyjnego i nabycia prawa własności przez nabywcę nie ma znaczenia fakt, czy w treści księgi wieczystej wpisany był jako właściciel dłużnik - osobisty albo rzeczowy - czy też osoba trzecia. Bez znaczenia pozostaje także ewentualna dobra bądź zła wiara nabywcy. Nabywca nie musi wykazywać następstwa prawnego po osobie wpisanej w księdze wieczystej jako właściciel. Prawomocne postanowienie o przysądzeniu własności stanowi dla nabywcy tytuł własności nieruchomości, a do sprzedaży licytacyjnej w ramach postępowania egzekucyjnego nie mają zastosowania przepisy k.c. o umowie sprzedaży (Krakowiak 2011: 1280). Jedyną możliwością uchylenia się od skutków przetargu to niewykonanie warunków licytacyjnych, co przesądza o uznaniu nabycia prawa własności za nabycie pierwotne.

Wątpliwości mogą powstać w związku z okolicznością, że pozostają w mocy bez potrącenia ich wartości z ceny nabycia prawa ciążące na nieruchomości mocy ustawy (art. 1000 § 2 pkt 1 k.p.c.). Wskazane zostało bowiem wyżej, że przejście prawa własności na podmiot publicznoprawny następuje właśnie z mocy samego prawa. Jednakże przepis ten nie odnosi się do prawa własności uregulowanego w ten sposób, 
że prawem ciążącym na nieruchomości nie może być prawo własności. Własność jako prawo jest prawem najszerszym, zaś ciążące na nieruchomości, tj. właśnie na najszerszym prawie własności tej nieruchomości, inne prawa ograniczają tę własność. Wobec likwidacji hipoteki ustawowej zabezpieczającej należności publicznoprawne przepis ten pozostaje przepisem pustym (Barańska 2006: 1097; Krakowiak 2011: 1289). Jedyną możliwością pozostania prawa na gruncie wskazanego przepisu jest hipoteka ustawowa wskazana w art. 1037 § 3 k.p.c. (zob. Żyznowski 2012: 1340).

Pomimo braku obowiązku ujawnienia procedury wywłaszczeniowej prowadzonej na podstawie ZasInwDrP w treści księgi wieczystej nieruchomości organ prowadzący postępowanie winien co najmniej dokonać wpisu prawa własności w księdze po dokonanym wywłaszczeniu. Braki w tym zakresie będą skutkowały także niemożnością podniesienia zarzutów po wydaniu postanowienia o przysądzeniu własności. Uchybienia, o których mowa w treści art. 998 § 2 k.p.c., należy traktować w sposób jednolity, a podstawą zaskarżenia postanowienia nie mogą być jakiekolwiek uchybienia sprzed uprawomocnienia się przybicia. Prawomocność postanowienia o przybiciu powoduje swoistą prekluzję możliwości podnoszenia uchybień procesowych, które miały miejsce przed wydaniem tego postanowienia (por. Leśniak, Romańska 2013: 982).

Niezależnie od powyższego należy wskazać, że odszkodowanie wpłaca się do depozytu sądowego, jeżeli osoba uprawniona odmawia jego przyjęcia albo wypłata odszkodowania natrafia na trudne do przezwyciężenia przeszkody lub odszkodowanie za wywłaszczenie dotyczy nieruchomości o nieuregulowanym stanie prawnym (art. 133 ust. o gosp. nieruch.). Istotną dla rozstrzyganych kwestii może być sytuacja, w której trwa spór o własność nieruchomości. W literaturze wskazuje się, że w ramach warunku trudnych do przezwyciężenia przeszkód mieści się również spór o prawo własności. Skoro bowiem starosta nie może samodzielnie rozstrzygać sporów o własność nieruchomości, to w takiej sytuacji zachodzi przeszkoda prawna w skutecznej wypłacie odszkodowania (Mzyk 2012: 796).

Biorąc pod uwagę pierwotny charakter nabycia własności, brak konieczności związku między poprzednim właścicielem a nabywcą oraz wskazaną niemożność uczestnictwa organu w zaskarżalności postanowień wydanych w toku sądowego postępowania egzekucyjnego, przyjąć należy, że w takiej sytuacji prawo własności pozostanie przy nabywcy. Brak jest bowiem jakiejkolwiek normy, z której wynikałby wniosek odmienny. Samo zaś nabycie własności przez organ z mocy prawa jest argumentem niewystarczającym do przyjęcia, że własność nieruchomości będzie pozostawała mimo wskazanej procedury egzekucyjnej przy tym podmiocie.

\section{Zakończenie}

Postępowanie uregulowane w ZasInwDrP miało na celu przyśpieszenie i uproszczenie procedury wywłaszczeniowej. Zgadzając się z potrzebą i dobrymi intencjami, zauważyć należy, że odejście od podstawowego mechanizmu uzyskania prawa własności na cele 
publiczne może prowadzić do wielu konfliktów. Utrata własności następuje bowiem bez sformalizowanego postępowania. Stopień specjalnych rozwiązań ZasInwDrP pozwala przyjąć, że następuje zmniejszenie roli własności prywatnej, kosztem własności publicznej. Im łatwiejsze jest wywłaszczenie, im szerszy zakres celów, dla których może być ono wykorzystywana, im wreszcie niższe może być odszkodowanie tym słabsza ochrona własności (Stelmachowski, Zaradkiewicz 2013: 299).

Wskazać należy, że organ prowadzący postępowanie na podstawie ZasInwDrP powinien jak najszybciej złożyć odpowiedni wniosek do sądu wieczystoksięgowego. Zaniechanie tego obowiązku, poza ewentualną odpowiedzialnością odszkodowawczą, skutkować może uzyskaniem prawa własności przez inny podmiot - licytanta spełniającego warunki do przysądzenia własności, co może rodzić kolejne komplikacje i wstrzymać realizowaną inwestycję, względnie skutkować koniecznością ponownego przeprowadzenia postępowania i wypłatą następnego odszkodowania. Niezgłoszenie wniosku o ujawnienie prawa własności przez podmiot publicznoprawny narazi także tenże na niemożność zaskarżenia wydanego w toku postępowania egzekucyjnego orzeczenia. Brak odpowiedniego wniosku do sądu wieczystoksięgowego powoduje, że podmiot publicznoprawny pozbawiony jest uprawnień procesowych, bowiem może nie mieć żadnych informacji o toczącym się postępowaniu. Powyższe jest uzasadnione i prawdopodobne, jeżeli weźmie się pod uwagę brak konieczności badania treści księgi wieczystej nieruchomości w toku postępowania prowadzonego w ramach ZasInwDrP.

\section{Bibliografia}

\section{Literatura:}

Bagińska E., Parchomiuk J., 2010, Odpowiedzialność odszkodowawcza w administracji [w:] R. Hausner, Z. Niewiadomski, A. Wróbel (red.), System Prawa Administracyjnego, t. XII, Warszawa.

Barańska A., 2006, [w:] K. Piasecki (red.), Kodeks postępowania cywilnego, Komentarz, t. III, wyd. 4, Warszawa.

Gniewek E., 2013, [w:] E. Gniewek (red.), System Prawa Prywatnego, Prawo rzeczowe, t. III, wyd. 3, Warszawa.

Krakowiak M., 2011, [w:] J. Jankowski (red.), Kodeks postępowania cywilnego, postępowanie egzekucyjne, Komentarz do artykułów 758-1088, Warszawa.

Kućka M., 2014, [w:] J. Pisuliński (red.), Księgi wieczyste i hipoteczne, Komentarz, Warszawa.

Langa-Bieszki H., Świeczkowski J., 2005, [w:] Z. Szczurek (red.), Kodeks postępowania cywilnego, postępowanie zabezpieczajace i egzekucyjne, Komentarz, Sopot.

Leśniak O., Romańska M., 2013, Postępowanie zabezpieczajq̨ce i egzekucyjne, Komentarz, wyd. 2, Warszawa.

Mzyk E., 2012, [w:] S. Kalus (red.), Ustawa o gospodarce nieruchomościami, Komentarz, Warszawa.

Rudnicki S., 2010, Ustawa o księgach wieczystych i hipotece, Komentarz, wyd. 6, Warszawa.

Skrzydło W., 2013, Konstytucja Rzeczypospolitej Polskiej, Komentarz, wyd. 7, Warszawa. 
Stelmachowski A., Zaradkiewicz K., 2013, [w:] E. Gniewek (red.), System Prawa Prywatnego, Prawo rzeczowe, t. III, wyd. 3, Warszawa.

Wolian M., 2010, Ustawa o szczególnych zasadach przygotowania i realizacji inwestycji w zakresie dróg publicznych, Komentarz, wyd. 2, Warszawa.

Żyznowski T., 2012 [w:] K. Piasecki, A. Marciniak (red.), Kodeks postępowania cywilnego, Komentarz, t. III, wyd. 5, Warszawa.

\section{Orzecznictwo:}

Wyrok SN z dnia 18 listopada 1993 r., III ARN 49/93, Legalis nr 28321.

Wyrok SN z dnia 22 września 1997 r., II CKN 730/97, Legalis nr 31594.

Postanowienie SN z dnia 13 czerwca 2013 r., IV CSK 666/12, Legalis nr 753902.

Wyrok WSA w Łodzi z dnia 4 lipca 2013 r., II SA/Łd 535/13, Legalis nr 788956.

Postanowienie SN z dnia 18 września 2014 r., V CSK 533/13, Legalis nr 1062224.

\section{Biogramy}

Łukasz Kamiński - radca prawny, doktorant na Wydziale Prawa i Administracji Uniwersytetu Gdańskiego. Zainteresowania naukowe: bancassurance, prawo cywilne, zobowiązania, prawo gospodarcze.

Piotr Kamiński - student drugiego roku na wydziale Prawa i Administracji Uniwersytetu Gdańskiego. Zainteresowania naukowe: prawo cywilne, zobowiązania, historia prawa, psychologia behawioralna, prawo karne, wiktymologia. 